mgr inż. Tymoteusz Rasiński

dr in.. Maciej Michnej

Politechnika Krakowska

\title{
Application of hybrid drives in diesel locomotives
}

\section{Zastosowanie napędów hybrydowych w lokomotywach spalinowych}

\begin{abstract}
Limitation of the toxic substances emission into the atmosphere in transport is one of the main priorities of the European Commission. The transport is increasingly contributing to air pollution. The alternative sources of energy and popularization of the sustainable ways of traveling and freight transport are the solution to this problem. This will allow not only to limit the pollutant emissions and reduce the fuel consumption, but also to reduce the operating costs of rail vehicles. In this article the authors analysed the structural solutions of hybrid drives in the rail vehicles and carried out an assessment of these solutions in terms of functionality and operation. As a result of the carried out analysis, the concept of hybrid drives for the basic series of diesel locomotives operated in Poland was presented.
\end{abstract}

Ograniczenie emisji toksycznych substancji do atmosfery $w$ transporcie jest jednym $z$ głównych priorytetów Komisji Europejskiej. Coraz większy udział w zanieczyszczeniu powietrza ma transport. Rozwiqzaniem tego problemu sq alternatywne źródła energii oraz popularyzacja zrównoważonych sposobów podróżowania i transportu ładunków. Pozwoli to nie tylko na ograniczenie emisji zanieczyszczeń i zmniejszenie zużycia paliwa, ale również na obniżenie kosztów eksploatacji pojazdów szynowych. W niniejszym artykule autorzy dokonali analizy rozwiazań konstrukcyjnych napędów hybrydowych $w$ pojazdach szynowych oraz przeprowadzili ocene tych rozwiazań pod względem funkcjonalności $i$ eksploatacji. $W$ wyniku przeprowadzonej analizy przedstawiono koncepcje napędów hybrydowych dla podstawowych serii lokomotyw spalinowych eksploatowanych $w$ Polsce.

\section{Introduction}

In the last few years due to the more and more restrictive environmental standards, the European Union countries strive to limit the negative impact of transport on the environment. The growing number of vehicles with diesel engines, i.e. cars, trucks, railway vehicles, causes an increase in the emission of hydrocarbons, carbon monoxide, carbon dioxide and nitrogen oxides. Therefore, it is necessary to work on

\section{Wprowadzenie}

W ostatnich kilku latach, w związku z coraz bardziej restrykcyjnymi normami środowiskowymi, państwa Unii Europejskiej dążą do ograniczenia negatywnego wpływu transportu na środowisko. Rosnąca liczba pojazdów z silnikami spalinowymi, tj. samochodów, ciężarówek, pojazdów kolejowych, powoduje wzrost emisji węglowodorów, tlenku węgla, dwutlenku węgla i tlenków azotu. Dlatego też konieczne 
alternative sources of vehicle power supply that will help to limit the emission of toxic pollutants into the atmosphere. One of such solutions is a hybrid drive system, which allows to reduce the unit fuel consumption and to recover a large amount of energy while operating of the vehicle. Initially, this system was implemented only in the construction of passenger cars and buses, and now it is also quite popular in diesel traction vehicles [1].

Large costs resulting from the maintenance of outdated railway rolling stock inclined the railway companies to invest in the new technologies and to the more and more popular using of alternative energy sources. In order to reduce the operating costs and increase the efficiency, the works were started on the use of hybrid drive in the rail vehicles. Despite the high initial costs, this investment can be relatively quick to pay back due to the reduction of fuel consumption, additionally allowing to limit the negative impact of transport on the environment.

\section{Analysis of hybrid drive systems}

Currently the market of hybrid traction vehicles in Europe is in the development phase. The leading producers of this type of solution are the following concerns: General Electric from the United States, Railpower Technologies Corporation from Canada and Toshiba Corporation from Japan. These companies, as one of the first, have implemented locomotives with hybrid drive to operation due to the modernization of old combustion shunting and line locomotives [2].

\subsection{Railpower Technologies Corp.}

In 2001. Railpower Technologies Corporation began working on the first prototype of a hybrid diesel locomotive. This prototype gave the basis for the development of GK10B and GG20B shunting locomotives as well as RP20BH and RP20BD line locomotives in the following years. A generating set is used in them, consisting of a diesel engine and a synchronous generator. This set generates electricity, which is stored in the high-capacity battery storage units. Traction engines, depending on the demand, can be powered by converters from the main generator or energy accumulated in batteries. The microprocessor system is responsible for the optimal use of the stored energy. Depending on the operational use of the vehicle, the appropriate number of battery modules and the power of the diesel engine are selected $[1,3]$.

In hybrid locomotives designed for GK10B shunting movement (Fig. 1) and GG20B (Fig. 2) due to the nature of their operation, the diesel engine is used only for charging the battery modules. It allows to significantly reduce the idle fuel consumption, constituting from 50 to $80 \%$ of the total working time of shunting locomotives [4] są prace nad alternatywnymi źródłami zasilania pojazdów, które pozwolą ograniczyć emisję toksycznych zanieczyszczeń do atmosfery. Jednym $z$ takich rozwiązań jest hybrydowy układ napędowy, który pozwala na zmniejszenie jednostkowego zużycia paliwa oraz odzysk dużej ilości energii podczas eksploatacji pojazdu. Początkowo system ten wdrażano jedynie w konstrukcjach samochodów osobowych i autobusów, a obecnie dość dużą popularność zyskuje również w pojazdach trakcji spalinowej [1].

Duże koszty wynikające $\mathrm{z}$ utrzymania przestarzałego taboru skłaniają przedsiębiorstwa kolejowe do inwestowania $\mathrm{w}$ nowe technologie oraz do coraz powszechniejszego wykorzystywania alternatywnych źródeł energii. W celu zmniejszenia kosztów eksploatacji oraz zwiększenia wydajności, rozpoczęto prace nad zastosowaniem napędu hybrydowego w pojazdach szynowych. Pomimo wysokich kosztów początkowych inwestycja ta może stosunkowo szybko się zwrócić ze względu na zmniejszenie zużycia paliwa, dodatkowo pozwalając na ograniczenie negatywnego wpływu środków transportu na środowisko.

\section{Analiza hybrydowych układów napędowych}

Aktualnie rynek hybrydowych pojazdów trakcyjnych w Europie jest w fazie rozwojowej. Wiodącymi producentami tego typu rozwiązania są koncerny, tj.: General Electric ze Stanów Zjednoczonych, Railpower Technologies Corporation z Kanady oraz Toshiba Corporation z Japonii. Przedsiębiorstwa te, jako jedne z pierwszych, dzięki modernizacji starych spalinowych lokomotyw manewrowych i liniowych, wdrożyły do eksploatacji lokomotywy z napędem hybrydowym [2].

\subsection{Railpower Technologies Corporaton}

W 2001 roku firma Railpower Technologies Corporation rozpoczęła prace nad pierwszym prototypem lokomotywy spalinowej $\mathrm{z}$ napędem hybrydowym. Prototyp ten dał bazę do powstania w kolejnych latach, lokomotyw manewrowych GK10B i GG20B oraz liniowych RP20BH i RP20BD. Zastosowano w nich zespół prądotwórczy, składający się z silnika spalinowego oraz prądnicy synchronicznej. Zespół ten generuje energię elektryczną, która magazynowana jest w wysokowydajnych zasobnikach akumulatorowych. Silniki trakcyjne w zależności od zapotrzebowania mogą być zasilane za pomocą przekształtników z prądnicy głównej lub energią zgromadzoną w bateriach. Za optymalne wykorzystanie zmagazynowanej energii odpowiada system mikroprocesorowy. W zależności od eksploatacyjnego przeznaczenia pojazdu dobierana jest odpowiednia ilość modułów akumulatorowych oraz moc silnika spalinowego $[1,3]$.

W lokomotywach hybrydowych przeznaczonych do ruchu manewrowego GK10B (rys. 1) i GG20B (rys. 2) ze względu na charakter ich pracy, silnik spalinowy wykorzystuje się jedynie do ładowania modu- 


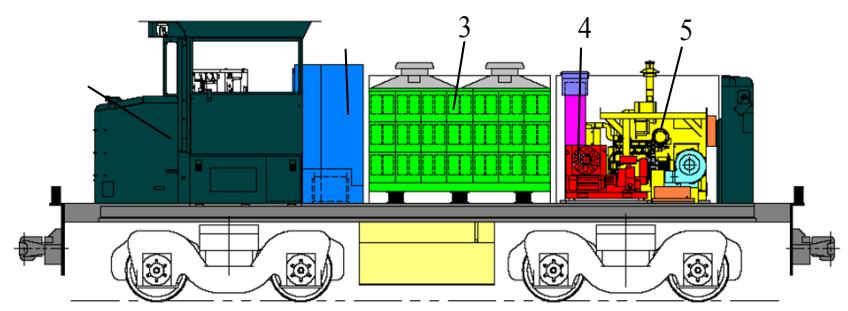

Fig. 1. Locomotive of GK10B series of Railpower Technologies Corp. company [5]

Rys. 2. Lokomotywa serii GK10B firmy Railpower Technologies Corp. [5]

1 - driver's cab; 2 - electrical equipment; 3 - battery module; 4 compressor; 5 - generating set

1 - kabina maszynisty; 2 - wyposażenie elektryczne; 3 - moduł baterii; 4 - sprężarka; 5 - zespół prądotwórczy

In the hybrid diesel locomotives, however, used for the line motion RP20BH (Fig. 3) and RP20BD (Fig. 4), a large diesel engine was replaced with two smaller drive units, supported by battery storage units. This solution allows to reduce the emission of harmful pollutants and noise during passage through the urbanized area, thanks to the use of energy accumulated in the batteries.

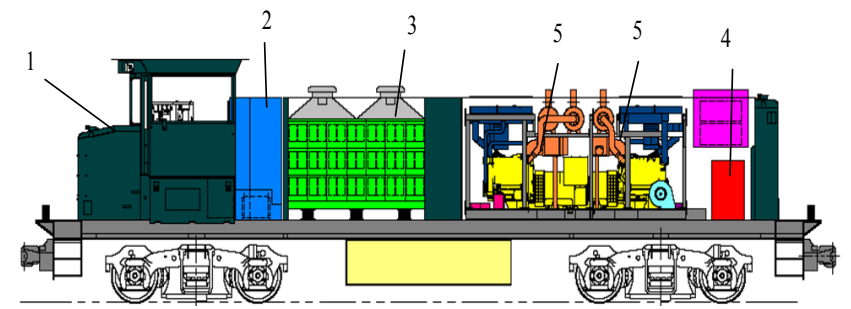

Fig. 3. Locomotive of RP20BH series of Railpower Technologies Corp. company [5]

Rys. 3. Lokomotywa serii RP20BH firmy Railpower Technologies Corp. [5]

1 - driver's cab; 2 - electrical equipment; 3 - battery module; 4 compressor; 5 - generating set

1 - kabina maszynisty; 2 - wyposażenie elektryczne; 3 - moduł baterii; 4 - sprężarka; 5 - zespół prądotwórczy

Technical data of hybrid locomotives built on the basis of the Railpower Technologies Corporation prototype is shown in Table 1. łów akumulatorowych. Pozwala to znacząco obniżyć zużycie paliwa na biegu jałowym, stanowiącym od 50 do $80 \%$ całkowitego czasu pracy lokomotyw manewrowych [4].

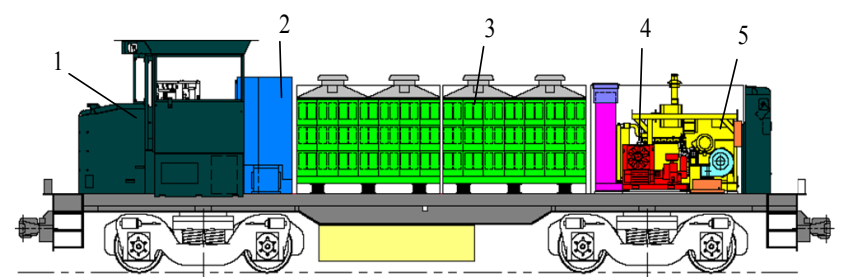

Fig. 2. Locomotive of GG20B series of Railpower Technologies Corp. company [5]

Rys. 2. Lokomotywa serii GG20B firmy Railpower Technologies Corp. [5]

1 - driver's cab; 2 - electrical equipment; 3 - battery module; 4 compressor; 5 - generating set

1 - kabina maszynisty; 2 - wyposażenie elektryczne; 3 - modul baterii; 4 - sprężarka; 5 - zespół prądotwórczy

W lokomotywach spalinowych z napędem hybrydowym wykorzystywanych do ruchu liniowego RP20BH (rys. 3) i RP20BD (rys. 4), duży silnik spalinowy zastapiono dwoma mniejszymi jednostkami napędowymi wspomaganymi przez zasobniki akumulatorowe. Takie rozwiązanie pozwala zredukować emisję szkodliwych zanieczyszczeń oraz hałas podczas przejazdu przez teren zurbanizowany, dzięki wykorzystaniu energii zgromadzonej w akumulatorach.

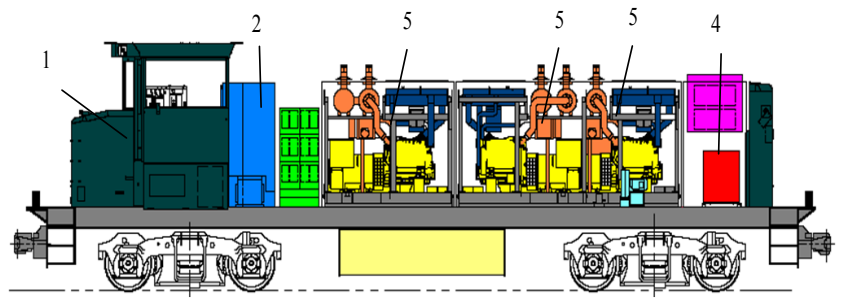

Rys. 4. Lokomotywa seriiRP20BD firmy Railpower Technologies Corp. [5]

Fig 4. Locomotive of RP20BD series of Railpower Technologies Corp. company[5]

1 - kabina maszynisty; 2 - wyposażenie elektryczne; 3 - moduł baterii; 4 - sprężarka; 5 - zespół prądotwórczy

1 - driver's cab; 2 - electrical equipment; 3 - battery module; 4 compressor; 5 - generating set

\begin{tabular}{|c|c|c|c|c|}
\hline \multirow{2}{*}{\multicolumn{2}{|c|}{ Serie lokomotyw }} & \multicolumn{3}{|c|}{ Parametry techniczne } \\
\hline & & \multirow{2}{*}{$\begin{array}{c}\begin{array}{c}\text { Moc } \\
\text { lokomotywy } \\
{[\mathbf{k W} / \mathbf{K M}]}\end{array} \\
735 / 1000\end{array}$} & \multirow{2}{*}{$\begin{array}{c}\begin{array}{c}\text { Moc silnika } \\
\text { spalinowego } \\
{[\mathbf{k W} / \mathbf{K M}]}\end{array} \\
88,2 / 120\end{array}$} & \multirow{2}{*}{$\frac{\text { Baterie }}{700 \mathrm{~V}_{\mathrm{DC}}, 600 \mathrm{Ah}}$} \\
\hline GG - & GK10B & & & \\
\hline & $G G 20 B$ & $1470 / 2000$ & 197 / 268 & $700 \mathrm{~V}_{\mathrm{DC}}, 1200 \mathrm{Ah}$ \\
\hline \multirow{2}{*}{$\begin{array}{l}\text { RP } \\
\text { liniowe }\end{array}$} & RP20BH & $1470 / 2000$ & $\begin{array}{l}490 / 667 \text { (dwa } \\
\text { silniki) }\end{array}$ & $700 \mathrm{~V}_{\mathrm{DC}}, 600 \mathrm{Ah}$ \\
\hline & RP20BD & $1470 / 2000$ & $\begin{array}{l}490 / 667 \text { (trzy } \\
\text { silniki) }\end{array}$ & $\begin{array}{l}\text { funkcja } \\
\text { pomocnicza }\end{array}$ \\
\hline
\end{tabular}

Dane techniczne lokomotyw hybrydowych Railpower Technologies Corporation [5] Tablica 1

Technical data of hybrid locomotives of Railpower Technologies Corporation [5] Table 1 


\subsection{General Electric}

In 2007. General Electric, as part of the Ecomagination program, presented its first prototype of a locomotive with the hybrid drive called the GE Evolution Hybrid (Fig.5). The modernized rail vehicle weighing 207 tons, in accordance with the initial assumptions, was supposed to save as much energy as it can be consumed by 160 households during the year $[1,2]$.

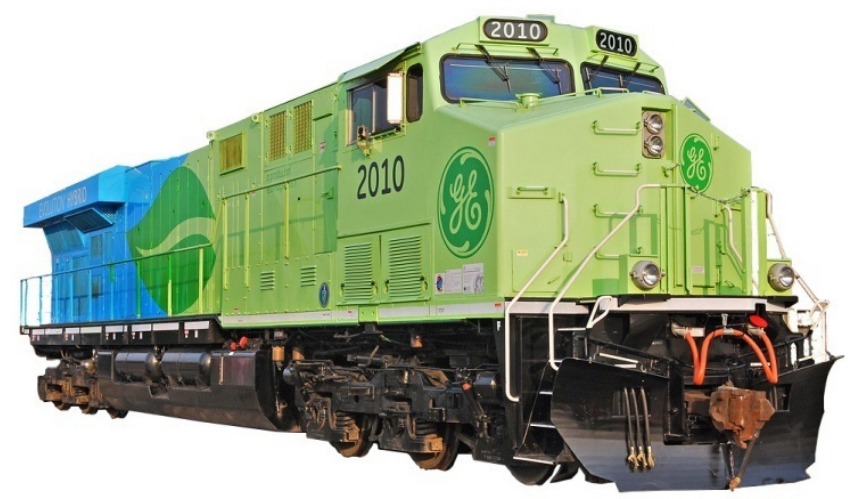

Fig. 5. GE Evolution Hybrid hybrid locomotive [1] Rys. 5. Lokomotywa hybrydowa GE Evolution Hybrid [1]

Currently GE Evolution Hybrid locomotives are commonly used for the line motion. In this case the hybrid system consists of a four-stroke diesel Gevo engine and several high-efficiency battery engines whose task is to intercept and store the energy recovered during recuperative braking. It can be used by engines to drive the vehicle during start-up. This allows to reduce fuel consumption by up to $15 \%$, thanks to the use of accumulated energy with an additional power of $1470 \mathrm{~kW}(2000 \mathrm{hp})$. The technology used in GE Evolution Hybrid also allows to reduce the toxic gas emissions into the environment by $50 \%$ in comparison with the standard locomotives of this type [2, 7]. The below scheme shows the hybrid drive system used in the GE Evolution Hybrid locomotive (Fig. 6).

\subsection{JR Freight Class HD300}

In 2010. Toshiba Logistic Corporation company presented a prototype of hybrid locomotive called HD300-901 (Fig.7). The aim of this investment was first of all the reduction of fuel consumption, as well as reduction of the noise level and the emission of harmful substances into the environment. The concept was to create the rail vehicle that was not only cheap to maintain, but also environmentally friendly. Thanks to the well-thought-out design, its modernization consisted in replacing the old engine with a modern drive unit and the installation of battery storage units [2].

Locomotives of the HD300 series are equipped with LIM30H-8A lithium-ion batteries, which are characterized by high efficiency and capacity, as well as resistance to extreme atmospheric conditions (low temperatures). The proper installation of battery stor-

\subsection{General Electric}

W 2007 roku firma General Electric, w ramach programu Ecomagination zaprezentowała swój pierwszy prototyp lokomotywy z napędem hybrydowym o nazwie GE Evolution Hybrid (rys. 5). Zmodernizowany pojazd szynowy, o masie 207 ton, zgodnie ze wstępnymi założeniami miał pozwolić na zaoszczędzenie $\mathrm{w}$ ciągu roku takiej ilości energii, jaką może zużyć 160 gospodarstw domowych [1,2].

Aktualnie lokomotywy GE Evolution Hybrid sa powszechnie wykorzystywane do ruchu liniowego. W tym przypadku układ hybrydowy składa się z czterosuwowego silnika wysokoprężnego Gevo oraz kilku wysokowydajnych silników akumulatorowych, których zadaniem jest przechwytywanie oraz magazynowanie energii odzyskanej $\mathrm{w}$ trakcie hamowania rekuperacyjnego. Może ona zostać wykorzystana za pomoca silników do napędzania pojazdu w trakcie rozruchu. Pozwala to zmniejszyć zużycie paliwa nawet o $15 \%$, dzięki skorzystaniu ze zgromadzonej energii o dodatkowej mocy $1470 \mathrm{~kW}$ (2000 KM). Technologia zastosowana w GE Evolution Hybrid umożliwia również obniżenie emisji toksycznych gazów do otoczenia o $50 \% \mathrm{w}$ porównaniu do standardowych lokomotyw tego typu $[2,7]$. Na poniższym schemacie przedstawiono układ napędu hybrydowego zastosowany w lokomotywie GE Evolution Hybryd (rys. 6).

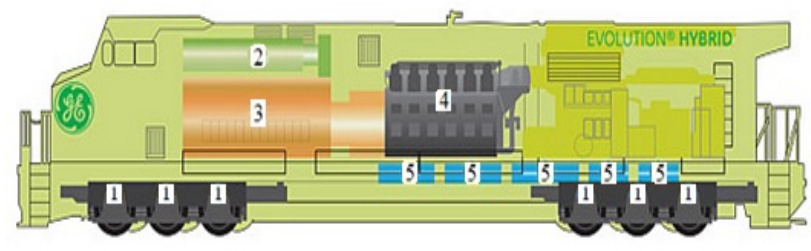

Fig. 6. Scheme of hybrid drive in GE Evolution Hybrid locomotive [7]

Rys. 6. Schemat napędu hybrydowego w lokomotywie GE Evolution Hybrid [7]

1 - traction engines; 2 - braking resistors; 3 - main generator; 4 diesel engine (ZS); 5 - batteries

1 - silniki trakcyjne; 2 - rezystory hamowania; 3 - prądnica główna; 4 - silnik spalinowy (ZS); 5 - akumulatory

\subsection{JR Freight Class HD300}

W 2010 roku firma Toshiba Logistic Corporation zaprezentowała prototyp lokomotywy z napędem hybrydowym o nazwie HD300-901 (rys. 7). Celem tej inwestycji było przede wszystkim zmniejszenie zużycia paliwa, a także obniżenie poziomu hałasu i zredukowanie emisji szkodliwych substancji do otoczenia. Koncepcja zakładała stworzenie pojazdu szynowego, nie tylko taniego w utrzymaniu, ale również przyjaznego dla środowiska. Jego modernizacja, dzięki przemyślanej konstrukcji, polegała na zastapieniu starego silnika nowoczesną jednostką napędową oraz na zabudowaniu w pojeździe zestawu zasobników akumulatorowych [2]. 
age units allows the vehicle to be powered even in the case of failure of one of the cell sets [8]. In the presented locomotive the hybrid drive of series type was used, characterized by two operating modes: braking (Fig. 8) and start-up (Fig. 9).

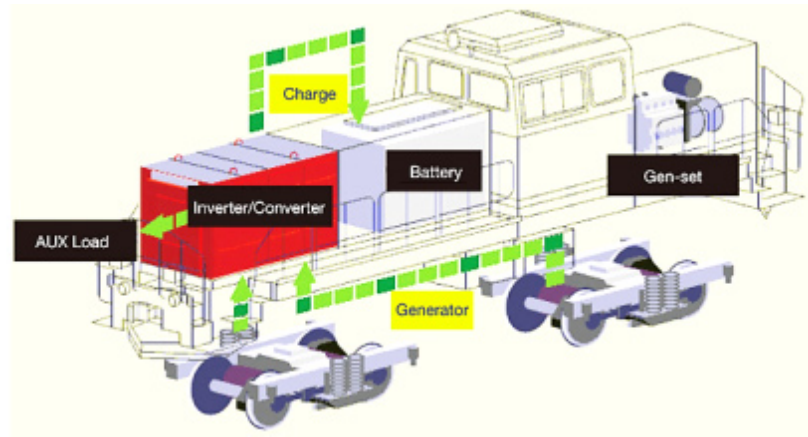

Fig. 8. Scheme of energy flow during braking of the vehicle [8] Rys. 8. Schemat przepływu energii w trakcie hamowania pojazdu [8]

The use of hybrid drive in JR Freight Class HD300 locomotives allowed to reduce the exhaust emissions and reduce the noise levels. In comparison with the diesel locomotives, the emissions of nitrogen oxides decreased by $62 \%$, fuel consumption by $36 \%$, while the noise level dropped to $22 \mathrm{~dB}$ for the engine operating at high rotational speed [2].

\section{Proposal of application of hybrid drive in diesel locomotives operated in Poland}

As a result of the inspection of diesel traction vehicles operated in Poland, in the context of the modernization consisting in using the hybrid drive, two diesel locomotives of SM48 and SP45 series were selected for further analysis.

The modernization of locomotives involves the replacement of an energy-consuming, heavy, largescale diesel engine with a modern, smaller and lighter drive unit. The conducted analysis of the use of power by the serial traction engines of the mentioned above locomotives showed that the rated power of the drive unit should be $1500 \mathrm{~kW}$. During choosing the diesel engine, the factors such as availability on the domestic market, modernity of the structure, purchase costs, maintenance costs, technical parameters concerning the compliance with applicable environmental standards and the availability of service and spare parts should be taken into account. These requirements are met, inter alia, by Caterpillar diesel engine of 3512 series, whose technical parameters are shown in Table 2.

Parametry techniczne silnika spalinowego firmy Caterpillar serii 3512 [9]

Tablica 2

Technical parameters of Caterpillar diesel engine of 3512 series [9]

Table 2

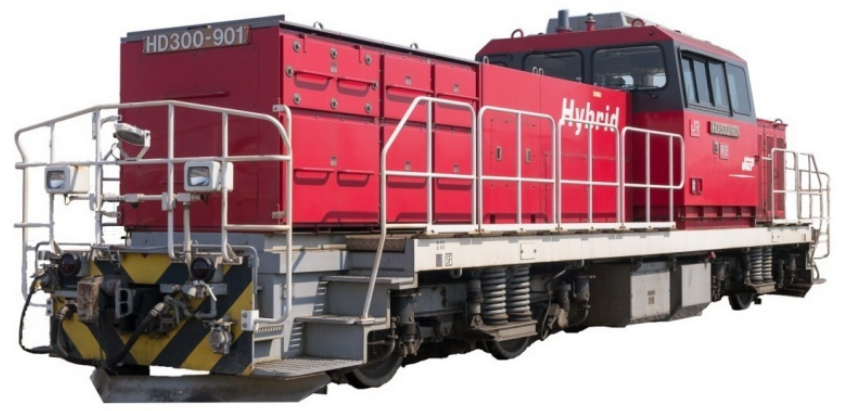

Fig. 7. JR Freight Class HD300 locomotive with hybrid drive [8] Rys. 7. Lokomotywa z napędem hybrydowym JR Freight Class HD300 [8]

Lokomotywy serii HD300 wyposażone zostały w akumulatory litowo-jonowe LIM30H-8A, które charakteryzuje wysoka wydajność i pojemność, a także odporność na skrajne warunki atmosferyczne (niskie temperatury). Odpowiednia zabudowa zasobników akumulatorowych pozwala na zasilanie pojazdu nawet w przypadku awarii jednego z zestawów ogniw [8]. W przedstawionej lokomotywie zastosowany został napęd hybrydowy typu szeregowego, charakteryzujący się dwoma trybami pracy: hamowania (rys. 8) i rozruchu (rys. 9).

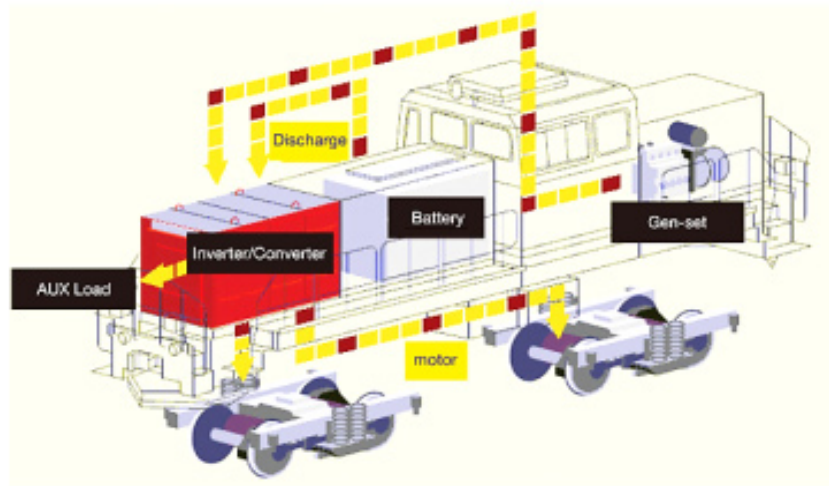

Fig. 9. Scheme of energy flow during start-up of the vehicle [8] Rys. 9. Schemat przepływu energii podczas rozruchu pojazdu [8]

Zastosowanie w lokomotywach JR Freight Class HD300 napędu hybrydowego pozwoliło na zmniejszenie emisji spalin i obniżenie poziomu hałasu. W porównaniu do lokomotyw spalinowych emisja tlenków azotu zmniejszyła się o $62 \%$, zużycie paliwa o $36 \%$, natomiast poziom hałasu spadł do poziomu 22 dB dla silnika pracującego przy dużych prędkościach obrotowych [2].

\section{Propozycja zastosowania napędu hybrydowego w lokomotywach spalinowych eksploatowanych w Polsce}

W wyniku przeglądu spalinowych pojazdów trakcyjnych eksploatowanych w Polsce, w kontekście modernizacji polegającej na zastosowaniu napędu hybrydowego, wytypowano do dalszej analizy dwie lokomotywy spalinowe serii: SM48 i SP45. 


\begin{tabular}{|c|c|c|}
\hline $\begin{array}{l}\text { Lp./ } \\
\text { Item }\end{array}$ & $\begin{array}{l}\text { Parametr/ } \\
\text { Parameter }\end{array}$ & $\begin{array}{l}\text { Wartość/ } \\
\text { Value }\end{array}$ \\
\hline 1 & $\begin{array}{l}\text { Moc nominalna/ } \\
\text { Nominal power }\end{array}$ & $1500 \mathrm{~kW}$ \\
\hline 2 & $\begin{array}{l}\text { Obroty nominalne/ } \\
\text { Nominal revolutions }\end{array}$ & $\begin{array}{l}1800 \\
{[\text { obr./min]/ }} \\
1800 \text { [r.p.m.] }\end{array}$ \\
\hline 3 & $\begin{array}{l}\text { Liczba cylindrów/ } \\
\text { Number of cylinders }\end{array}$ & 12 \\
\hline 4 & $\begin{array}{l}\text { Średnica tłoka/ } \\
\text { Diameter of piston }\end{array}$ & $170[\mathrm{~mm}]$ \\
\hline 5 & Skok tłoka/ Stroke of piston & $215[\mathrm{~mm}]$ \\
\hline 6 & $\begin{array}{l}\text { Pojemność skokowa silni- } \\
\text { ka/Engine cylinder capacity }\end{array}$ & $59\left[\mathrm{dm}^{3}\right]$ \\
\hline 7 & $\begin{array}{l}\text { Jednostkowe zużycie pali- } \\
\text { wa/Unit fuel consumption }\end{array}$ & $212[\mathrm{~g} / \mathrm{kWh}]$ \\
\hline 8 & $\begin{array}{l}\text { Norma dot. } \\
\text { spalin/Standard for } \\
\text { emission }\end{array}$ & IIIA, IIIB \\
\hline 9 & $\begin{array}{l}\text { Masa silnika suchego/ } \\
\text { Dry engine weight }\end{array}$ & $6863[\mathrm{~kg}]$ \\
\hline
\end{tabular}

The power of the diesel engine will be received by means of the synchronous generators set (main generator and auxiliary generator) produced by EMIT Żychlin. Their rated powers are $1400 \mathrm{~kW}$ for the main generator and $100 \mathrm{~kW}$ on the DC side for the auxiliary generator. The use of the maximum power of traction engines will cause an increase in the amount of heat that must be carried away to the cooling system. Therefore, when installing the hybrid system, it should be remembered to install the cooling units with radiators and fans powered by the asynchronous electric motors [9]. A very important stage is also the selection of appropriate battery storage unit. Their number and capacity depend on the operational use of the traction vehicle. The cells FNC® - A190 HRC of Hoppecke company, with a capacity of 190 Ah each, are characterized by not only the long durability and no need to replace the electrolyte, but also negligible operating costs. Their advantage is also the construction, because they consist of a cells set, which even allows, in the case of failure of one of them, to continue to power the vehicle [10].

Another important element of the entire hybrid system is the use of a converter/inverter, which is responsible for the conversion of the value of intensity and voltage of current to the rated voltage of the traction engines. In the case of traction engines, they will be covered only by modernization consisting in their sealing and replacement of the used subassemblies. The supervisory function of the entire hybrid drive system is carried out by the microprocessor controller, which supervises the optimal use of energy stored in the high-efficient battery storage units.

In order to install the hybrid drive in the diesel locomotive of SP45 series instead of the existing drive unit and the generator set, the following elements will be installed:
Modernizacja lokomotyw wiąże się z wymianą energochłonnego, ciężkiego, wielkogabarytowego silnika spalinowego, na nowoczesną, mniejszą i lżejszą jednostkę napędową. Przeprowadzona analiza wykorzystania mocy przez seryjne silniki trakcyjne ww. lokomotyw wykazała, że znamionowa moc jednostki napędowej powinna wynosić $1500 \mathrm{~kW}$. Dobierając silnik spalinowy, należy uwzględnić takie czynniki jak dostępność na rynku krajowym, nowoczesność konstrukcji, koszty nabycia, koszty utrzymania, parametry techniczne dotyczące spełnienia obowiązujących norm środowiskowych oraz dostępność serwisu i części zamiennych. Wymagania te spełnia między innymi typoszeregowy silnik spalinowy firmy Caterpillar serii 3512 , którego parametry techniczne zostały przedstawione w tablicy 2.

Moc z silnika spalinowego odbierana będzie za pomocą zespołu prądnic synchronicznych (prądnica główna i prądnica pomocnicza), produkcji firmy EMIT Żychlin. Ich moce znamionowe wynoszą 1400 $\mathrm{kW}$ w przypadku prądnicy głównej oraz $100 \mathrm{~kW}$ po stronie prądu stałego dla prądnicy pomocniczej. Wykorzystanie maksymalnej mocy silników trakcyjnych spowoduje wzrost ilości ciepła, które należy odprowadzić do układu chłodzenia. Dlatego przy zabudowaniu układu hybrydowego należy pamiętać o zainstalowaniu agregatów chłodniczych z radiatorami oraz wentylatorów zasilanych asynchronicznymi silnikami elektrycznymi [9]. Bardzo ważnym etapem jest również dobranie odpowiednich zasobników akumulatorowych. Ich liczba oraz pojemność uzależniona jest od eksploatacyjnego przeznaczenia pojazdu trakcyjnego. Spełniającymi założenia konstrukcji są ogniwa firmy Hoppecke FNC® - A190 HRC, o pojemności 190 Ah każde, charakteryzujące się nie tylko długą trwałością oraz brakiem konieczności wymiany elektrolitu, ale także znikomymi kosztami eksploatacyjnymi. Ich zaletą jest również budowa, składają się one bowiem z zestawu ogniw, co pozwala nawet w przypadku awarii jednego $\mathrm{z}$ nich na dalsze zasilanie pojazdu [10].

Kolejnym istotnym elementem całego układu hybrydowego jest zastosowanie konwertera/inwertera, który odpowiada za regulację napięcia zasilania silników trakcyjnych. W przypadku silników trakcyjnych zostaną one objęte jedynie modernizacją polegającą na ich uszczelnieniu oraz wymianie zużytych podzespołów. Funkcję nadzorczą nad całym hybrydowym układem napędowym sprawuje sterownik mikroprocesorowy, który czuwa nad optymalnym wykorzystaniem energii zgromadzonej w wysokowydajnych zasobników akumulatorowych.

Aby zainstalować napęd hybrydowy w lokomotywie spalinowej serii SP45 w miejsce dotychczasowej jednostki napędowej oraz zespołu prądnic, zabudowane zostaną następujące elementy: 
- Caterpillar 3512 diesel engine with rated power of $1500 \mathrm{~kW}$

- synchronous generator set of EMIT Żychlin, with rated power of $1400 \mathrm{~kW}$

- transducer set and converter.

However, under the two drivers' cabs the highefficient battery storage unts will be installed to collect energy for later use. The proposal for the use of hybrid drive system in the diesel locomotive of SP45 series is shown in the drawing below (Fig. 10).
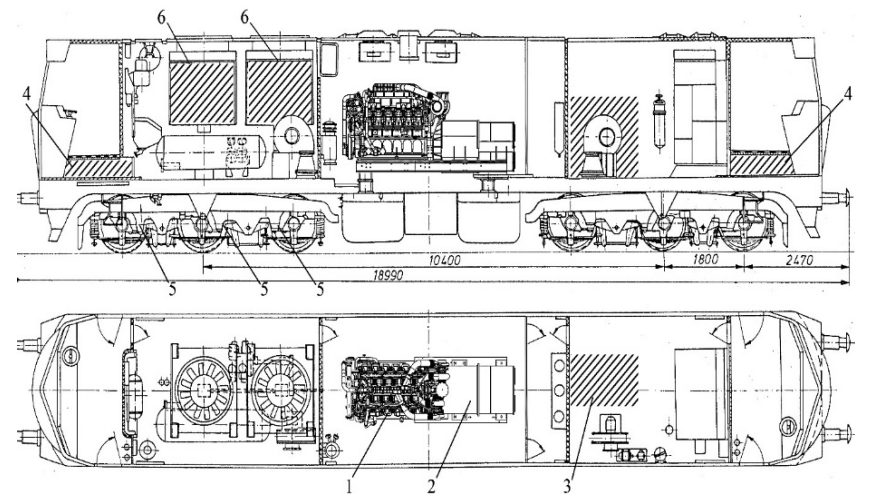

Fig. 10. Project of the arrangement of hybrid drive assemblies in the SP45 diesel locomotive

Rys. 10. Projekt rozmieszczenia zespołów napędu hybrydowego w lokomotywie spalinowej SP45

diesel engine (CAT3512); 2- synchronous generator set; 3converter; 4- battery storage units; 5 - traction engines; 6 - fan with asynchronous drive motor

1- silnik spalinowy (CAT3512); 2- zespół prądnic synchronicznych; 3-konwerter; 4- zasobniki akumulatorowe; 5silniki trakcyjne; 6 - wentylator $\mathrm{z}$ asynchronicznym silnikiem napędowym

In the case of the concept of using the hybrid drive in the SM48 diesel locomotive in the place of the current drive unit and the generator set, as part of the modernization, as in the SP45 series the following will be installed:

- Caterpillar 3512 diesel engine with rated power of $1500 \mathrm{~kW}$,

- synchronous generator set of Emit Żychlin with rated power of $1400 \mathrm{~kW}$,

- transducer set and converter.

As opposed to the previous concept, in this case high-efficient battery storage units will be installed in the made places in the electrical cabinet behind the driver's cab. The design of the arrangement of the drive system assemblies and subassemblies is presented in the drawing below (Fig. 11).

\section{Conclusions}

Taking into consideration the possibility of building in the hybrid drive assemblies and subassemblies on one of the locomotives operated in Poland, the popular diesel locomotives SP45 and SM48 were selected for modernization. The calculations made using the simple financial assessment methods showed that the undertaking consisting in modernization of an old
- silnik spalinowy Caterpillar 3512 o mocy znamionowej $1500 \mathrm{~kW}$

- zespół prądnic synchronicznych EMIT Żychlin, o mocy znamionowej $1400 \mathrm{~kW}$

- zespół przetworników i konwerter.

Pod dwoma kabinami maszynistów natomiast zamontowane zostaną wysokowydajne zasobniki akumulatorowe, służące do gromadzenia energii, w celu późniejszego jej wykorzystania. Propozycja zastosowania hybrydowego układu napędowego w lokomotywie spalinowej serii SP45 została przedstawiona na rysunku poniżej (rys. 10).

W przypadku koncepcji zastosowania napędu hybrydowego w lokomotywie spalinowej serii SM48 w miejscu dotychczasowej jednostki napędowej i zespołu prądnic, w ramach modernizacji zainstalowane zostana, podobnie jak w serii SP45:

- silnik spalinowy Caterpillar 3512 o mocy znamionowej $1500 \mathrm{~kW}$,

- zespół prądnic synchronicznych Emit Żychlin, o mocy znamionowej $1400 \mathrm{~kW}$,

- zespół przetworników i konwerter.

W odróżnieniu od poprzedniej koncepcji, w tym przypadku wysokowydajne zasobniki akumulatorowe zainstalowane zostana $\mathrm{w}$ wygospodarowanym miejscach w szafie elektrycznej za kabiną maszynisty. Projekt rozmieszczenia zespołów i podzespołów układu napędowego przedstawiono na rysunku poniżej (rys. 11).
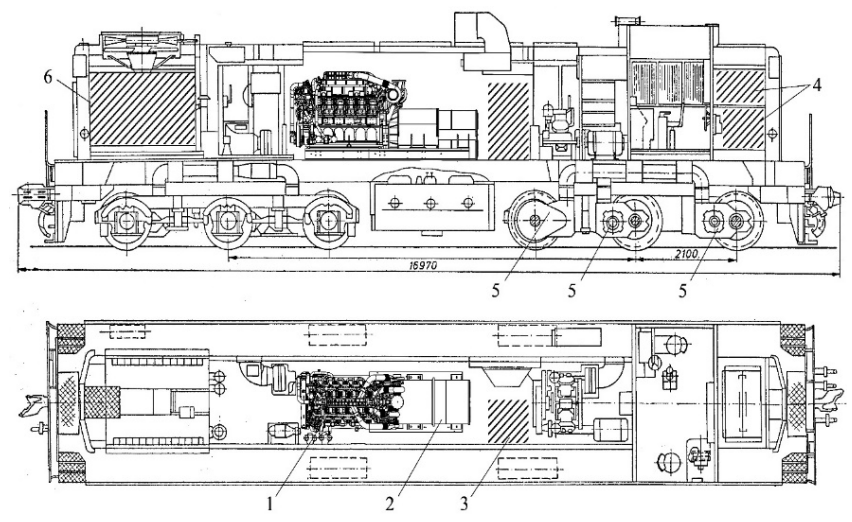

Fig. 11. Design of the arrangement of hybrid drive assemblies in the SP48 diesel locomotive

Rys. 11. Projekt rozmieszczenia zespołów napędu hybrydowego w lokomotywie spalinowej SM48

diesel engine (CAT3512); 2- synchronous generator set; 3- converter; 4- battery storage units; 5 - traction engines; 6 - fan with asynchronous drive motor

silnik spalinowy (CAT3512); 2- zespół prądnic synchronicznych; 3-konwerter; 4- zasobniki akumulatorowe; 5- silniki trakcyjne; 6 wentylator $\mathrm{z}$ asynchronicznym silnikiem napędowym

\section{Podsumowanie}

Biorąc pod uwagę możliwość zabudowania zespołów i podzespołów napędu hybrydowego na jednej z lokomotyw eksploatowanych w Polsce, do modernizacji wytypowano popularne lokomotywy spalinowe 
shunting locomotive into the hybrid locomotive should show the high profitability. This profitability is higher, the greater operation of the vehicle is during the year. Despite the high initial costs, the investment in the hybrid drive can bring many benefits not only economic but also operational and ecological. This solution allows to recover the significant amount of energy, which was previously lost in the form of heat. This reduces the unit fuel consumption and, consequently, limits the emission of harmful substances into the atmosphere.

\section{Bibliography / Bibliografia}

[1] Marciniak Z.: Hybrydowe uktady napędowe lokomotyw spalinowych. Logistyka, 4, 2010.

[2] Konarzewski M., Niezgoda T., Stankiewicz M., Szurgott P.: Hybrid locomotives overview of construction solutions. Journal of Kones Powertrain and Transport, Vol. 20, No. 1, 2013

[3] Michnej M., Szkoda M.: Wspótczesne rozwiazania hybrydowych układów napędowych spalinowych pojazdów trakcyjnych. TTS, 10/2007.

[4] Michnej M., Szkoda M.: Hybrydowe uktady napędowe spalinowych pojazdów trakcyjnych. Zeszyty Naukowe Politechniki Ślaskiej, 2008

[5] Materiaty ofertowe firmy Railpower Technologies Corp.

[6] Katuża E.: Hybrydowe lokomotywy manewrowe $w$ świetle efektywności eksploatacyjnej. Zeszyty Naukowe Politechniki Ślaskiej, Z.118, Gliwice, 1990.

[7] Kortas P., Kropiwnicki J.: Analiza możliwości akumulacji energii rozproszonej $w$ procesie hamowania pociagu napędzanego lokomotywa hybrydowa. Combustion Engines, 3, 2015

[8] Materiaty ofertowe firmy Toshiba Corporation

[9] Babet M., Szachniewicz B.: Studium techniczne - Modernizacja spalinowej lokomotywy manewrowej serii SM31. Czasopismo techniczne, 7-M, 2012.

[10] Marciniak Z., Mielniczuk J., Jakuszko W., Michalak P.: Konstrukcja uktadów napędu hybrydowego dla wybranych zmodernizowanych lokomotyw spalinowych do ruchu manewrowego i przetokowego. Pojazdy szynowe nr 2, 2014. serii SP45 oraz SM48. Kalkulacje wykonane za pomoca prostych metod oceny finansowej wykazały, że przedsięwzięcie polegające na modernizacji starej lokomotywy manewrowej, na lokomotywę hybrydową powinno wykazywać wysoką opłacalność. Opłacalność ta jest tym wyższa, im większe jest eksploatacyjne wykorzystanie pojazdu w ciagu roku. Pomimo wysokich początkowych kosztów, inwestycja w napęd hybrydowy może przynieść wiele korzyści nie tylko ekonomicznych, ale również eksploatacyjnych oraz ekologicznych. Takie rozwiązanie pozwala na odzyskanie znacznej ilości energii, która wcześniej była wytracana w postaci ciepła. Powoduje to zmniejszenie jednostkowego zużycia paliwa, a w konsekwencji ograniczenie emisji szkodliwych substancji do atmosfery. 